\title{
Adrenomedullin in pancreatic carcinoma: A case-control study of 22 patients
}

\author{
$D^{\prime}$ Angelo Francesco ${ }^{1}$, Letizia Claudio ${ }^{2}$, Antolino Laura ${ }^{1 *}$, La Rocca Mara ${ }^{1}$, Aurello Paolo ${ }^{1}$ and Ramacciato Giovanni ${ }^{1}$ \\ ${ }^{1}$ Department of Surgery and Translational Medicine, Faculty of Medicine and Psychology, Sapienza University of Rome, Rome, Italy \\ ${ }^{2}$ Department of Internal Medicine and Medical Specialties, Specialized Center of Secondary Hypertension, Umberto I General Hospital, Sapienza University of \\ Rome, Rome, Italy
}

\begin{abstract}
Pancreatic carcinoma is a leading cause of cancer-related death. Reduction of the diagnostic delay is mandatory. Adrenomedullin (AM) is overexpressed in pancreatic cancer. A case-control study including 12 patients with pathological diagnosis of pancreatic carcinoma and 10 healthy controls was conducted at our Institution. Blood samples were obtained at the time of hospitalization and post-operatively for cases. Controls' samples were obtained from healthy volunteers. AM was measured by using enzyme immunoassay method. AM showed significant increase in pancreatic carcinoma patients vs controls $(4.51 \mathrm{ng} / \mathrm{ml} \mathrm{vs} 1.91 \mathrm{ng} / \mathrm{ml}, \mathrm{p}$ value $=0.04)$ regardless of tumor stage, differentiation, resecability/unresecability, diabetes. A cut-off of $1.75 \mathrm{ng} / \mathrm{ml}$ reaches a sensibility of $83 \%$ and a specificity of $70 \%$ ( $p$ value $=0.0147$; CL 95\%; AUC 0.767). The increase of AM didn't correlate with the increase of other common tumor markers (CA 19-9 and CEA), nor direct bilirubin. These data confirm the utility of studying the role of AM in pancreatic cancer, in order to achieve an early diagnosis in high risk populations.
\end{abstract}

\section{Introduction}

Pancreatic carcinoma $(\mathrm{PaC})$ is the fourth leading cause of cancerrelated death in the western World [1] and its incidence is increasing in sexes $(+0.8 \%$ per year males; $+2.0 \%$ per year females $)$ [2]. Up to now surgical resection is the only curative option for those patients [3]. Overall survival at 5 -years for resected patients reaches a $43 \%$ rate [4] compared to a global 5 -years survival rate of $5 \%{ }^{3}$. However, only $20 \%$ of patients are diagnosed with a resectable disease, and a complete resection (R0) is achieved in less than 10\% [5]. Late clinical signs and absence of specific tests are responsible for the delay in the diagnosis of $\mathrm{PaC}$ [3]. Currently, CA $19-9$ is the only marker acknowledged worldwide for $\mathrm{PaC}$ diagnosis $[2,6]$, and the main limitations to its use are low specificity [6-8] and late increase on disease progression [2]. Adrenomedullin (AM) is up-reguleted in pancreatic cancer [9] and it is investigated as a possible diabetogenic mediator [9]. Both cancer cells and neighboring pancreatic tissue show AM overexpression independently from the stage of the neoplastic disease [9]. The aim of this study was to evaluate serum AM levels with cytological and/or histological diagnosis of $\mathrm{PaC}$ compared to non-cancer controls. This represents the validation phase of a larger prospective study that aims to evaluate the role of $\mathrm{AM}$ in the early detection of $\mathrm{PaC}$ in a high risk population: new-onset diabetic patients [ClinicalTrials.gov Identifier: NCT02456051].

\section{Materials and methods}

From November 2013 through August 2014, 16 patients presenting with suspect of pancreatic carcinoma to the Department of General Surgery of St Andrea University Hospital in Rome were evaluated. Patients were enrolled in the study according to the following criteria: pancreatic adenocarcinoma confirmed by cytological or histological sample; written informed consent provided by each patient; age 18-90. Exclusion criteria were: other than ductal adenocarcinoma pancreatic neoplasm; other synchronous malignancies; post operative sepsis or renal failure signs. The main characteristics of the patients are summarized in Table 1. 10 non-cancer volunteers were enrolled in the study as controls, and this population is homogeneous to the cases in terms of age and sex. Their characteristics are summarized in Table 2.

Blood samples were obtained at the time of hospitalization and, when resection was feasible, post-operatively in $7^{\text {th }}$ post-operative day. Each blood sample was centrifuged (4000 RPM for 10 minutes), divided into $1.5 \mathrm{ml}$ aliquots and stored up at $-18^{\circ} \mathrm{C}$. AM was measured by using commercially available EIA method (Adrenomedullin (Human) EIA Kit, Phoenix Pharmaceuticals, Inc.Mountain View, CA,USA). The intra- and inter-assay coefficients were $5.1 \%$ and $12 \%$, respectively.

For statistical analysis Excel program $\left(\mathrm{Microsoft}^{\circledR}\right)$ has been utilized. T-test was applied to compare serum levels of AM in the study groups. Comparisons were: $\mathrm{PaC}$ patients vs non-cancer controls; among the $\mathrm{PaC}$ population, earlier stages vs later stages, more differentiated vs less differentiated, resectable vs unresectable, diabetics vs no diabetics; among the operated population, preoperative levels vs postoperative levels. Linear regression and Pearson coefficient were evaluated to detect possible correlation between serum levels of AM and CA 19-9, $\mathrm{CEA}$, direct bilirubin. Correlations between AM and preoperative FPG and $\mathrm{AM}$ and diabetes duration were analyzed too.

Correspondence to: Laura Antolino, Department of Surgery and Translational Medicine, Faculty of Medicine and Psychology, Sapienza University of Rome, Via di Grottarossa 1035/1039, 00189 Rome, Italy, Tel: (+39)06-33775632; E-mail: laura.antolino@uniroma1.it

Key words: pancreatic carcinoma; adrenomedullin; diabetes; pancreatic oncomarker

Received: February 25, 2016; Accepted: March 11, 2016; Published: March 14, 2016 
Table 1. Characteristics of the patients affected by pancreatic adenocarcinoma.

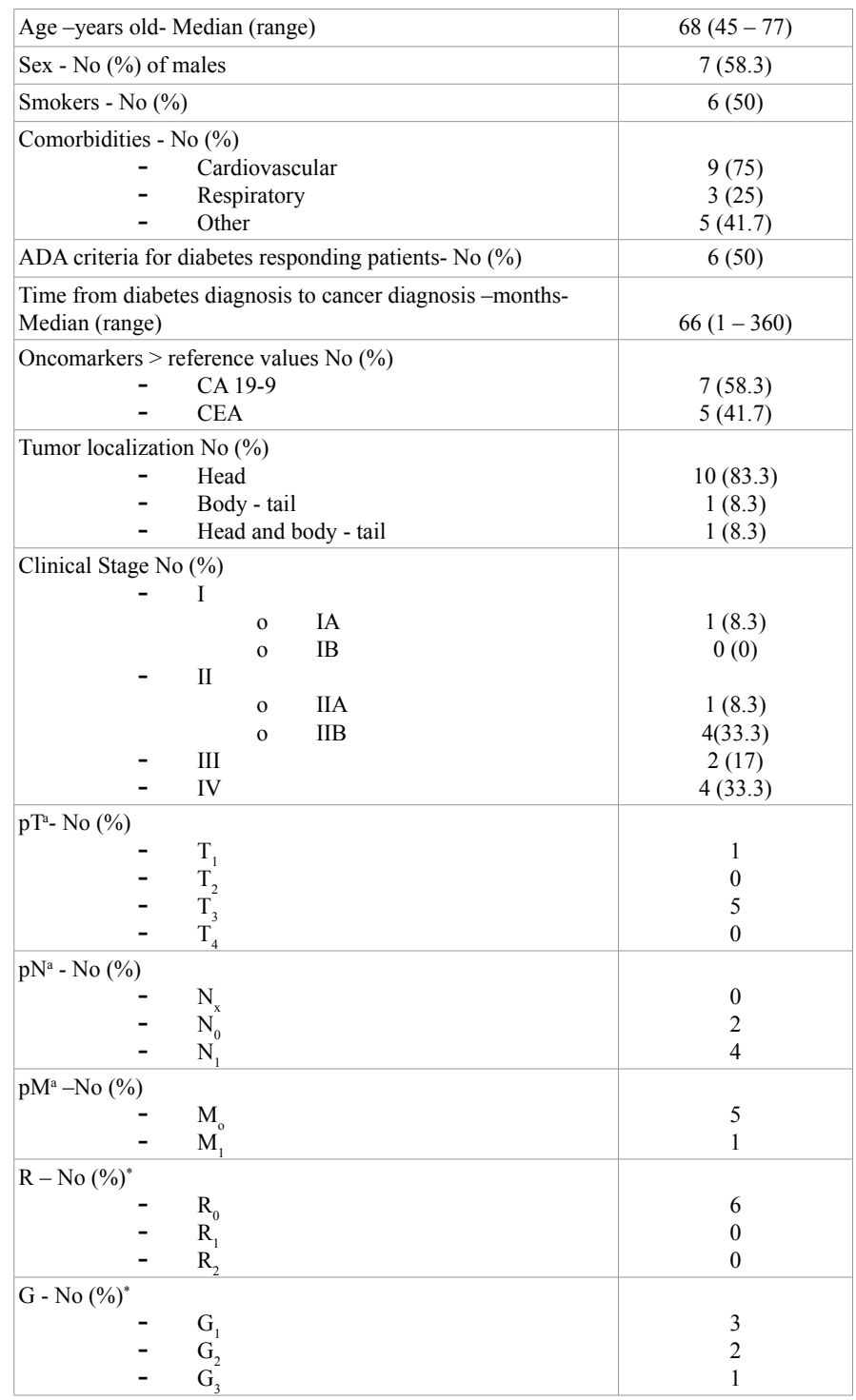

${ }^{\text {a }}$ pTNM was evaluated in resectable patients ( 6 of 12)

Table 2. Characteristics of noncancer controls

\begin{tabular}{|c|c|}
\hline Age -years old- Median (range) & $55(25-90)$ \\
\hline Sex - N. $(\%)$ of males & $6(60)$ \\
\hline Smokers N. (\%) & $6(60)$ \\
\hline Diabetes N. (\%) & $1(10)$ \\
\hline $\begin{aligned} \text { Comorbidities N. } & (\%) \\
- & \text { Cardiovascular } \\
- & \text { Respiratory } \\
- & \text { Other }\end{aligned}$ & $\begin{array}{c}3(30) \\
0(0) \\
3(30)\end{array}$ \\
\hline
\end{tabular}

$\mathrm{P}$ value was assumed significant when $<0.05$. ROC curve for AM was designed to detect the serum cut-off concentration with the best sensitivity and specificity. The study was conducted in the respect of the principles of Helsinki declaration [10].

\section{Results}

12 out of 16 patients were included in the study after histological diagnosis of pancreatic adenocarcinoma. The other 4 were excluded for different histological findings. 6 patients underwent a complete tumor resection while the remaining 6 patients received palliative care or chemotherapy regimens. Mean serum AM level in $\mathrm{PaC}$ patients at the time of hospitalization was $4.51 \mathrm{ng} / \mathrm{ml}$ (range $0.04-9.16 \mathrm{ng} / \mathrm{ml}$, SD 3.17). Resected patients had a preoperative mean serum AM level of $4.94 \mathrm{ng} / \mathrm{ml}$ (range $0.04-9.16 \mathrm{ng} / \mathrm{ml}, \mathrm{SD} 3.56$ ) and a postoperative mean serum AM level was $2.13 \mathrm{ng} / \mathrm{ml}$ (range $0.47-3.77 \mathrm{ng} / \mathrm{ml}$, SD 1.60). The mean decrease of serum AM was $2.8 \mathrm{ng} / \mathrm{ml}$ (range $-0.43-8.11$, SD 3.14) but wasn't statistically significant $(\mathrm{p}=0.12)$. Serum AM was significantly increased in $\mathrm{PaC}$ patients than in controls $(4.51 \mathrm{ng} / \mathrm{ml} \mathrm{vs}$ $1.91 \mathrm{ng} / \mathrm{ml} ; \mathrm{p}=0.04$ ) (Table 3 and 4). All other comparisons are shown in Table III. None of the correlations investigated with CA19.9, CEA, bilirubin, FPG and diabetes duration was significant (Table 4 and 5). ROC curve pointed out that a cut-off of $1.75 \mathrm{ng} / \mathrm{ml} \mathrm{AM} \mathrm{had} \mathrm{a} \mathrm{sensitivity}$ of $83 \%$ and a specificity of $70 \%$ ( $p$ value $=0.0147$; CL 95\%; AUC 0.767) to distinguish cases from controls (Figure 1).

\section{Discussion}

Diagnostic delay is responsible for the high mortality of $\mathrm{PaC}$, which

Table 3. Serum AM levels mean (and Standard Deviation) of the compared groups and respective $\mathrm{p}$ value.

\begin{tabular}{|l|c|c|c|}
\hline \multicolumn{1}{|c|}{ Mean (SD) } & Mean (SD) & P value \\
\hline PaC patients VS Controls & $4.51 \mathrm{ng} / \mathrm{ml}(3.17)$ & $1.91 \mathrm{ng} / \mathrm{ml}(2.20)$ & 0.04 \\
\hline Stage I-II VS Stage III-IV & $5.05 \mathrm{ng} / \mathrm{ml}(3.97)$ & $4.96 \mathrm{ng} / \mathrm{ml}(2.51)$ & 0.86 \\
\hline G1 VS G2 & $6.68 \mathrm{ng} / \mathrm{ml}(3.86)$ & $2.61 \mathrm{ng} / \mathrm{ml}(3.63)$ & 0.93 \\
\hline Resectable VS Unresectable & $4.94 \mathrm{ng} / \mathrm{ml}(3.56)$ & $4.75 \mathrm{ng} / \mathrm{ml}(2.80)$ & 0.93 \\
\hline Preoperative VS Postoperative & $4.94 \mathrm{ng} / \mathrm{ml}(3.56)$ & $2.13 \mathrm{ng} / \mathrm{ml}(1.60)$ & 0.12 \\
\hline Diabetic VS No diabetic & $5.45 \mathrm{ng} / \mathrm{ml} \mathrm{(3.10)}$ & $3.57 \mathrm{ng} / \mathrm{ml} \mathrm{(3.22)}$ & 0.33 \\
\hline
\end{tabular}

Table 4. Correlation between serum AM levels and serum CA 19-9, CEA and direct bilirubin levels.

Pearson coefficient ( $\mathrm{R}^{2}$ and $\mathrm{p}$ value)

\begin{tabular}{|l|c|}
\hline AM - CA 19-9 & $0.345(0.119 ;>0.2)$ \\
\hline AM - CEA & $-0.28(0.08 ;>0.5)$ \\
\hline AM - Direct Bil. & $0.26(0.07 ;>0.2)$
\end{tabular}

Table 5. Correlation between serum AM levels and FPG and duration of diabetes.

AM - FPG

Pearson coefficient $\left(\mathrm{R}^{2}\right.$ and $\mathrm{p}$ value $)$

AM - diabetes duration

$0.28(0.08 ;>0.2)$

$0.57(0.33 ;>0.2)$

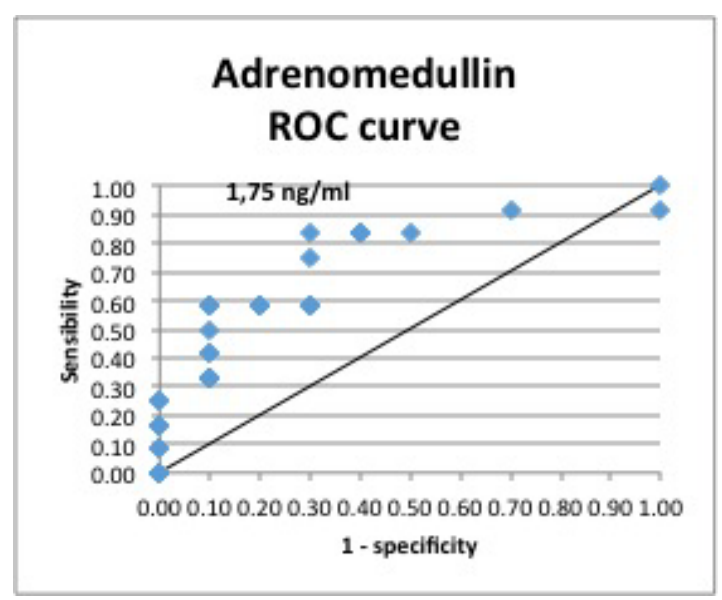

Figure 1. Adrenomedullin (AM) ROC curve. Cut-off $1.75 \mathrm{ng} / \mathrm{ml}$ AM (sensitivity 83\%, specificity $70 \%$, p val Adrenomedullin ue 0.0147 , CL 95\%, AUC 0.767). 
almost coincides with its incidence [1,3]. PaC-related symptoms are late-onset in the natural history of the disease [3], therefore early serum markers are needed. Unfortunately, the ones currently available are related to late stages, and so are unuseful in detecting a resectable disease [2]. This urge to seek new diagnostic markers led us to investigate the role of Adrenomedullin in $\mathrm{PaC}$. The interest for $\mathrm{AM}$ arises from recent studies that investigated PaCDM mediators [12-14]. AM is a 52-amino acid peptide discovered in 1993 [15]. It is physiologically produced by human organism [16] but its secretion increases in multiple pathological conditions, such as endothelial damage, heart failure, hypertension, renal failure, sepsis and hypoxia $[17,18]$. Physiologically $\mathrm{AM}$ is recognized as a regulator of the pancreatic secretion $[14,19,20]$, while in pancreatic cancer, it is overexpressed in both neoplastic and peritumoral tissues. Circulating levels are increased too [9]. Recently new-onset diabetes mellitus has been investigated as a possible early manifestation of pancreatic cancer (PaCDM). $50 \%$ of patients affected by $\mathrm{PaC}$ are diabetic, $70 \%$ of whom were diagnosed for being diabetic less than 2 years before tumor diagnosis [12]. Moreover, PaCDM is an early manifestation of the disease and develops when the tumor is resectable in $55 \%-65 \%$ of the cases [21]. In our population AM did not show any correlation with DM presence. We might hypothesize that $\mathrm{AM}$ is over-expressed in all $\mathrm{PaC}$ patients and that only subjects likely to develop diabetes reveal the effects of $\beta$-cell dysfunction. In this study we included only pancreatic ductal adenocarcinomas, which is the most frequent histological type of pancreatic carcinoma to avoid confounding factors deriving from heterogeneity of histology [3]. In our population serum $\mathrm{AM}$ showed a significant increase in $\mathrm{PaC}$ patients but do not correlate with tumor stage, differentiation or resectability. AM levels do not show any relation neither with pre-operative FPG or length of diabetes. Those characteristics could configure AM as an early tumor marker: its stage-independence makes it a promising diagnostic tool. Moreover, AM showed a decreasing trend after resection, even if not in a statistically significant way. We can hypothesize that dosing the peptide later than the $7^{\text {th }}$ pod would have allowed a better washout and, consequently lower AM levels. These preliminary data confirm the tight relationship between Adrenomedullin and Pancreatic Cancer. Further studies are needed to investigate the role of AM as early diagnostic tool in high risk populations.

\section{Acknowledgments}

The authors thank Giovanni Clemente and Gerardo Salerno for their support and contribution during the study conduct. Gerardo Salerno also gave his contribution for the statistical analysis.

\section{Disclosure}

The presented results represent the validation phase of a larger prospective study that aims to evaluate the role of AM in the early detection of $\mathrm{PaC}$ in a high risk population: new-onset diabetic patients [ClinicalTrials.gov Identifier: NCT02456051]. The funds to support this research were provided by Sapienza - University of Rome.

\section{References}

1. Siegel R, Ward E, Brawley O, Jemal A (2011) Cancer statistics, 2011: the impact of eliminating socioeconomic and racial disparities on premature cancer deaths. $C A$ Cancer J Clin 61: 212-236.[Crossref]

2. (2013) AIOM. Lineeguida: Carcinoma del pancreas esocrino. [Online]. [http://www. aiom.it/area+pubblica/area+medici/Prodotti+scientifici/linee+guida/1,333,1.]

3. Wolfgang CL, Herman JM, Laheru DA, Klein AP, Erdek MA, et al. (2013) Recent progress in pancreatic cancer. CA Cancer J Clin 63: 318-348.[Crossref]

4. Winter JM, Cameron JL, Campbell KA, Arnold MA, Chang DC, et al. (2006) 1423 pancreaticoduodenectomies for pancreatic cancer: A single-institution experience. $J$ Gastrointest Surg 10: 1199-1210.[Crossref]

5. Chari ST (2007) Detecting early pancreatic cancer: problems and prospects. Semin Oncol 34: 284-294.[Crossref]

6. Wu E, Zhou S, Bhat K, Ma Q (2013) CA 19-9 and pancreatic cancer. Clin Adv Hematol Oncol 11: 53-55.[Crossref]

7. Mann DV, Edwards R, Ho S, Lau WY, Glazer G (2000) Elevated tumour marker CA199: clinical interpretation and influence of obstructive jaundice. Eur J Surg Oncol 26 : 474-479.[Crossref]

8. Marrelli D, Caruso S, Pedrazzani C, Neri A, Fernandes E, et al. (2009) CA19-9 serum levels in obstructive jaundice: clinical value in benign and malignant conditions. Am J Surg 198: 333-339.[Crossref]

9. Aggarwal G, Ramachandran V, Javeed N, Arumugam T, Dutta S, et al. (2012) Adrenomedullin is up-regulated in patients with pancreatic cancer and causes insulin resistance in $\beta$ cells and mice. Gastroenterology 143: 1510-1517.[Crossref]

10. World Medical Association (2013) World Medical Association Declaration of Helsinki: ethical principles for medical research involving human subjects. JAMA 310: 21912194.[Crossref]

11. Conlon KC, Klimstra DS, Brennan MF (1996) Long-term survival after curative resection for pancreatic ductal adenocarcinoma. Clinicopathologic analysis of 5-year survivors. Ann Surg 223: 273-279.[Crossref]

12. Pannala R, Leirness JB, Bamlet WR, Basu A, Petersen GM, et al. (2008) Prevalence and clinical profile of pancreatic cancer-associated diabetes mellitus. Gastroenterology 134: 981-987.[Crossref]

13. Basso D, Greco E, Fogar P, Pucci P, Flagiello A, et al. (2006) Pancreatic cancer-derived S-100A8 N-terminal peptide: a diabetes cause? Clin Chim Acta 372: 120-128.[Crossref]

14. Sah RP, Nagpal SJ, Mukhopadhyay D, Chari ST (2013) New insights into pancreatic cancer-induced paraneoplastic diabetes. Nat Rev Gastroenterol Hepatol 10: 423-433. [Crossref]

15. Kitamura K, Kangawa K, Kawamoto M, Ichiki Y, Nakamura S, et al. (1993) Adrenomedullin: a novel hypotensive peptide isolated from human pheochromocytoma. BiochemBiophys Res Commun 192: 553-560.[Crossref]

16. Jougasaki M, Burnett JC Jr (2000) Adrenomedullin: potential in physiology and pathophysiology. Life Sci 66: 855-872.[Crossref]

17. Julián M, Cacho M, García MA, Martín-Santamaría S, de Pascual-Teresa B, et al (2005) Adrenomedullin: a new target for the design of small molecule modulators with promising pharmacological activities. Eur J Med Chem 40: 737-750.[Crossref]

18. Keleg S, Kayed H, Jiang X, Penzel R, Giese T, et al. (2007) Adrenomedullin is induced by hypoxia and enhances pancreatic cancer cell invasion. Int J Cancer 121: 21-32. [Crossref]

19. López J, Cuesta N (2002) Adrenomedullin as a pancreatic hormone. Microsc Res Tech57: 61-75.[Crossref]

20. Tsuchida T, Ohnishi H, Tanaka Y, Mine T, Fujita T (1999) Inhibition of stimulated amylase secretion by adrenomedullin in rat pancreatic acini. Endocrinology 140: 865870.[Crossref]

21. Pelaez-Luna M, Takahashi N, Fletcher JG, Chari ST (2007)Resectability of presymptomatic pancreatic cancer and its relationship to onset of diabetes: a retrospective review of $\mathrm{CT}$ scans and fasting glucose values prior to diagnosis. $\mathrm{Am} \mathrm{J}$ Gastroenterol 102: 2157-2163.[Crossref]

Copyright: (C) 2016 Francesco D. This is an open-access article distributed under the terms of the Creative Commons Attribution License, which permits unrestricted use, distribution, and reproduction in any medium, provided the original author and source are credited. 